\title{
Efthymios Nicolaidis
}

Director of Research, Institute of Historical Research,

National Hellenic Research Foundation

President of the International Union of the History and Philosophy of Science and Technology / Division of History of Science and Technology, Member of the Council of the International Academy of History of Science efnicol@eie.gr

\section{Éloge to Robert Fox}

\begin{abstract}
The $20^{\text {th }}$ Alexandre Koyré Medal awarded since 1968 to prominent historians of science was awarded to Robert Fox, leading historian of European science of the period from the $18^{\text {th }}$ to the beginnings of the $20^{\text {th }}$ century. The Medal was presented to Robert Fox during the $7^{\text {th }}$ International Conference of the European Society for the History of Science, Prague, 23 September 2016, and the Éloge describes his career and work.
\end{abstract}

Keywords: Robert Fox, Alexandre Koyré Medal in 2016, International Academy of the History of Science, $7^{\text {th }}$ International Conference of the European Society for the History of Science, Prague, 23 September 2016.

\begin{tabular}{|c|c|c|c|c|c|}
\hline \multicolumn{2}{|c|}{$\begin{array}{l}\text { PUBLICATION } \\
\text { INFO }\end{array}$} & $\begin{array}{r}\text { Ptudia } \\
\text { Pistoriae } \\
\text { cientiarum }\end{array}$ & $\begin{array}{r}\text { e-ISSN 2543-702X } \\
\text { ISSN 2451-3202 }\end{array}$ & smid & $\begin{array}{c}2 \\
\text { DIAMOND } \\
\text { OPEN ACCESS }\end{array}$ \\
\hline \multicolumn{6}{|c|}{$\begin{array}{l}\text { CITATION } \\
\text { Nicolaidis, Efthymios 2017: Éloge to Robert Fox. Studia Historiae Scientiarum 16, pp. 21-27. } \\
\text { Available online: } \underline{\text { https://doi.org/10.4467/2543702XSHS.17.003.7704. }}\end{array}$} \\
\hline \multicolumn{3}{|c|}{$\begin{array}{l}\text { RECEIVED: } 16.01 .2017 \\
\text { ACCEPTED: 06.12.2017 } \\
\text { PUBLISHED ONLINE: } 18.12 .2017\end{array}$} & $\begin{array}{l}\text { ARCHIVE } \\
\text { POLICY } \\
\text { Green SHERPA/ } \\
\text { RoMEO Colour }\end{array}$ & 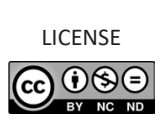 & Crossref \\
\hline www & \multicolumn{5}{|c|}{$\underline{\text { http://pau.krakow.pl/Studia-Historiae-Scientiarum/; http://www.ejournals.eu/si/index.php/SHS/ }}$} \\
\hline
\end{tabular}




\title{
Pochwała Roberta Foxa
}

\begin{abstract}
Abstrakt
Medal Alexandre'a Koyré'ego jest przyznawany od 1968 r. wybitnym historykom nauki. Dwudziesty medal trafil do Roberta Foxa, czołowego historyka europejskiej nauki z okresu od XVIII do początków XX wieku. Wręczono go 23 września 2016 roku w Pradze podczas VII Międzynarodowej Konferencji Europejskiego Towarzystwa Historii Nauki. W Pochwale przedstawiono opis kariery i pracy Laureata.
\end{abstract}

Słowa kluczowe: Robert Fox, Medal Alexandre'a Koyréego za 2016 r., Miedzynarodowa Akademia Historii Nauki, VII Miedzynarodowa Konferencja Europejskiego Towarzystwa Historii Nauki, Praga, 23 września 2016 r.

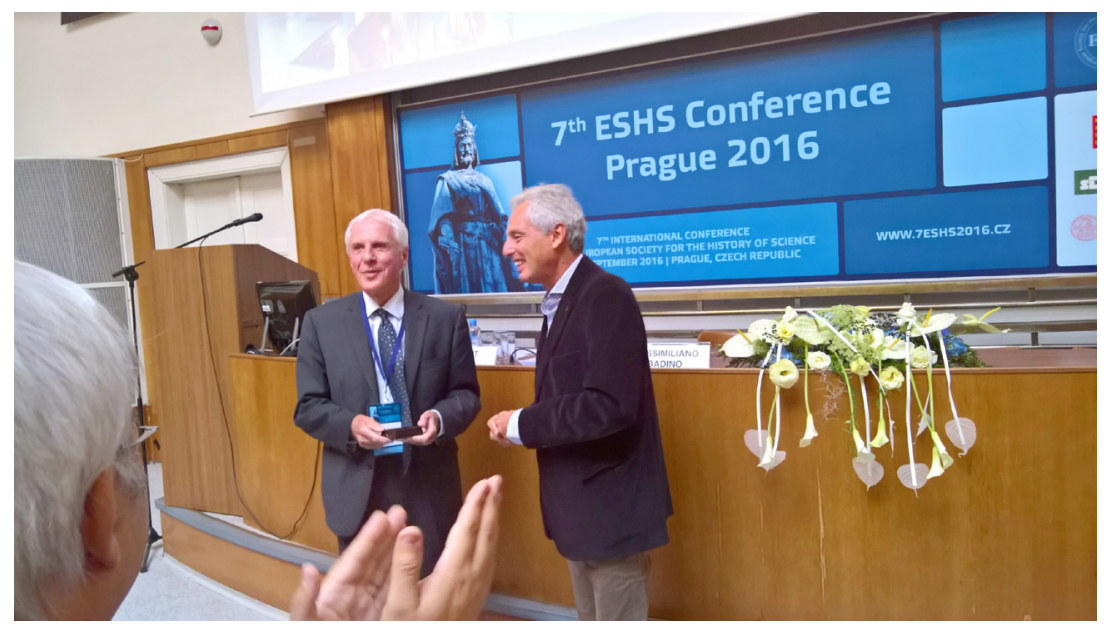

Fig. 1. Robert Fox and Efthymios Nicolaidis. The ceremony of awarding the $20^{\text {th }}$ Alexandre Koyré Medal to Robert Fox. The $7^{\text {th }}$ International Conference of the European Society for the History of Science, Prague, 23 September 2016. Photo by courtesy of Jan Vandersmissen. Private archive of Efthymios Nicolaidis.

Thank you for coming to this important event, ${ }^{1}$ and let me at first present the apologies of the Perpetual Secretary of the International

${ }^{1}$ That is awarding Alexandre Koyré Medal of the International Academy of the History of Science to Robert Fox. This ceremony took place in Prague on 23 September 2016, during the $7^{\text {th }}$ International Conference of the European Society. 
Academy of History of Science, professor Robert Halleux. Due to a temporary health problem he was not able to come as planned to Prague and present himself this Koyré medal to the laureate.

Robert Fox will have his birthday in exactly fifteen days. Not need to tell you his year of birth since he is an eternal young colleague and he never ceased to be active in the field of history of science. In his long career he has formed and continues to form a multitude of scholars and has promoted history of science in Europe and in the whole world. The European Society of the History of Science is among the institutions that Robert has founded since he fostered the idea of it and was its founding president from 2003 to 2006. Thirteen years after the ESHS foundation, I feel very honoured, to present during this Congress, on behalf of the International Academy of the History of Science, the prestigious Koyré medal to Robert Fox, whose works have inspired me in my intellectual and research life. This is the $20^{\text {th }}$ Koyré medal; the first one was given in 1968 to Derek Thomas Whiteside for the first two volumes of his monumental edition The Mathematical Papers of Isaac Newton. The $20^{\text {th }}$ medal is awarded to Robert Fox for all his writings and his career contribution.

Robert Fox studied physics in Oxford. Immediately after his Master degree in physics he continued his studies at the Faculty of Modern History of Oxford under the supervision of Alistair Cameron Crombie, and obtained a $\mathrm{PhD}$ in philosophy for a thesis entitled The study of the thermal properties of gases in relation to physical theory from Montgolfier to Regnault. This thesis inaugurated his long career as a leading historian of European science of the period from the $18^{\text {th }}$ to the beginnings of the $20^{\text {th }}$ century. His critical edition at the age of thirty of the Réflexions sur la puissance motrice du feu of Sadi Carnot made Robert Fox famous among the international milieu of the historians of science; revised editions of the book have been published in English, German and Italian. Robert has until today authored or edited seventeen important books about history of science.

I am just reminding you The culture of science in France, 1700-1900 and Science, technology, and the social order in post-revolutionary France published both in the collection Variorum, which summarise his works on the subject until 1995; The savant and the state. Science and cultural politics in nineteenth-century France published by Johns Hopkins University Press in 2012. Recently, Robert has offered the community of historians of 
science an important handbook, the Oxford handbook of the bistory of physics, a volume coedited with Jed Buchwald and published in 2013. And the young Robert has just published his last book titled Science without frontiers. Cosmopolitanism and national interest in the world of learning, 1870-1940. In this new book, Robert Fox explores the discipline of science as a model for global society.

Let me quote from the description of this important book:

Fostered by international congresses and societies, scientific collaboration flourished across linguistic and national borders from the mid-nineteenth century up until, and even after, the First World War. Projects such as the universal language Esperanto and the Dewey decimal system relied on optimistic visions of the future and were fuelled by dramatic improvements in communications and transportation... After the First World War, scientific internationalism met with a new set of challenges as governments increasingly sought to control the uses of science and technology. Fox details the fate of cooperative scientific internationalism in Europe and the challenges posed to it by the rise of totalitarianism and the increasingly conflicting force of nationalism. He explores public expressions of scientific nationalism in museum exhibits and, most tellingly, in rival national pavilions at such celebrations of internationalism as the Paris International Exposition of 1937.

Robert Fox has also published articles and chapters in books that have marked the historiography of European science. Just to mention one of the first and one of the latest, I will make reference to "The rise and fall of Laplacian physics" published in 1974 in the Historical studies in the physical sciences and "Linderman and Einstein: the Oxford connection" published in 2015 in a collective volume in the series "Boston Studies in the Philosophy and History of Science".

From the history of physics of the $18^{\text {th }}$ century to institutional and political history of science of the $20^{\text {th }}$, the works of Robert Fox cover a wide range of topics; they have and continue to develop new approaches and they shape new trends in the field of history of science. It is why Robert Fox is not known only by historians of science; 
his work has also influenced other historical fields and belong to global history.

Robert has a long career of teacher with a capital T. His first position was assistant Master of physics at Tonbridge School, Kent. Soon he became Lecturer, then Senior Lecturer, then Reader, then Professor of the History of Science at the University of Lancaster where he taught for 22 years. Our French colleagues do remember his participation to the French institutional life as director, from 1986 to 1988 of the Centre de Recherche en Histoire des Sciences et des Techniques, the newly created research unit of the Cité des Sciences et de l'Industrie. Just after, Robert Fox became Assistant Director and Head of the Research and Information Services Division of Science Museum, London and at the same time Professor of the History of Science and Professorial Fellow of Linacre College, University of Oxford. From 2006 he is emeritus professor of the University of Oxford.

Robert played also an important role in the social life of our field: active member of numerous societies, he has been President of the British Society of the History of Science, President of the Division of History of Science of the International Union of History and Philosophy of Science and, as I mentioned before, President of the ESHS. Robert has also been for six years editor of the prestigious British Journal for the History of Science. His contribution to the international academic life has been rewarded by numerous distinctions. Among those, Fellow of the Society of Antiquaries, Chevalier de l'Ordre des Palmes Académiques, Dickinson Medal of the Newcomen Society, Oskar von Miller Gold Medal of the Deutsches Museum, Chevalier de l'Ordre des Arts et des Lettres, he has been elected to an Honorary Fellowship at Oriel College and last year to the European Academy of Sciences.

I would like to end this brief éloge to Robert Fox with a personal note. When I met him for the first time, some decades ago, he was already a prestigious scholar whose works were of reference to historians of science. As a young scholar newly introduced in the international milieu of our field, you can imagine that I felt nervous in approaching the famous professor. I can assure you that in a few seconds I felt at ease: Robert has the talent to listen to people and help them tactfully when they ignore a topic. Combining British phlegm and French enthusiasm, he is a universal scholar, a cosmopolitan savant in the world of learning. 


\section{Bibliography}

Buchwald, Jed Z.; Fox, Robert (eds.) 2013: The Oxford handbook of the history of physics. Oxford: Oxford University Press. ISBN 9780199696253.

Centre D’Historia de la Ciencia 2015: Robert Fox, catedrático emérito de Historia de la Ciencia de la Universidad de Oxford, en la celebración del 20 aniversario del CEHIC (19/10/2015). Available online: http://www.cehic.es/ficha noticies. php? sitelang $=$ es\&idnoti $=353$.

Fox, Robert 1967: The study of the thermal properties of gases in relation to physical theory from Montgolfier to Regnault. Doctoral Thesis. Oxford: Oxford University.

Fox, Robert 1971: The caloric theory of gases from Lavoisier to Regnault. Oxford: The Clarendon Press. Pp. xvi + 378. ISBN 9780198581314.

Fox, Robert 1974: The Rise and Fall of Laplacean Physics. Historical Studies in the Physical Sciences 4, pp. 89-136. Available online: https://doi.org/10.2307/27757328 (purchase PDF). Stable URL: http://www.jstor.org/stable/27757328.

Fox, Robert 1978: Sadi Carnot. Réflexions sur la puissance motrice du feu. Edition critique avec introduction et commentaire, augmentée de documents d'archives et de divers manuscrits de Carnot. Paris: Librairie Philosophique J. Vrin. Pp. 371; also editions in English (1986: Sadi Carnot. Reflections on the Motive Power of Fire: a Critical Edition with the Surviving Scientific Manuscripts. Manchester: Manchester University Press, New York: Lilian Barber Press; ISBN 978-0-936508-16-0), German (1988), and Italian (1992).

Fox, Robert 1992: The culture of science in France, 1700-1900. Aldershot: Variorum. Pp. xiii + 335. ISBN 9780860783398.

Fox, Robert 2006: Curriculum Vitae. Available online: http://www.ecu.edu/cs-cas/ harriot/upload/fox cv.doc.

Fox, Robert 2015: Lindemann and Einstein: The Oxford Connexion. In: Ana Simões, Jürgen Renn \& Theodore Arabatzis (eds.), Relocating the History of Science. "Boston Studies in the Philosophy and History of Science" 312 (Springer Verlag). Chapter 3, pp. 23-31. Available online: https://books.google.pl/ books?id=QV51CQAAQBAJ\&pg=PA23.

Fox, Robert 2016: Science without Frontiers: Cosmopolitanism and National Interests in the World of Learning, 1870-1940. Corvallis, Oregon, USA: Oregon State University Press.

Fox, Robert 2017: The dream that never dies: the ideals and realities of cosmopolitanism in science, 1870-1940. Studia Historiae Scientiarum 16, pp. 29-47. Available online: https://doi.org/10.4467/2543702XSHS.17.004.7705. 


\section{Focal Point $\mid \begin{array}{r}\text { Pistoriae } \\ \text { tudia }\end{array}$}

The History of Science Society 2015: Science Society's Sarton Medal. Available online: https://web.archive.org/web/20160712192918/http://www.chemheritage. org/about/news-and-press/press-releases/2015-11-24-robert-fox-awarded-thehistory-of-science-societys-sarton-medal.aspx.

Whiteside, Derek Thomas 1967-1974: The Mathematical Papers of Isaac Newton the first three volumes with the assistance in publication of M. A. Hoskin, the other volumes with the assistance in publication of M. A. Hoskin and A. Prag). Vol. I 1664-1666 (1967, 638 pp., illus.); vol. II 1667-1670 (1968, 556 pp., illus.); vol. III 1670-1673 (1969, 626 pp., illus.); vol. 4 1674-1684 (1971, 722 pp., illus.); vol. 5 1683-1684 (1972, 660 pp., illus.); vol. $61684-1691$ (1974, 614 pp., illus.). Cambridge: Cambridge University Press. Available online: http://assets. cambridge.org/97805210/45858/frontmatter/9780521045858 frontmatter.pdf.

Wikipedia 2017: Robert Fox (historian). Available online: https://en.wikipedia.org/ wiki/Robert_Fox_(historian). 